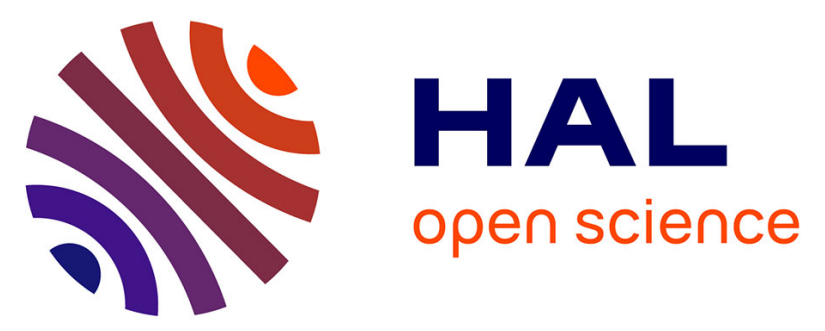

\title{
From local to regional 3D litho-structural modelling: a methodology towards multi-scale landslide susceptibility and hazard assessment
}

Lucie Guillen, Séverine Caritg, Pierre Bourbon, Thomas Dewez, Clara Lévy, Alessia Cuccurullo, Christophe Garnier, Domenico Gallipoli, Yannick Thiery

\section{To cite this version:}

Lucie Guillen, Séverine Caritg, Pierre Bourbon, Thomas Dewez, Clara Lévy, et al.. From local to regional 3D litho-structural modelling: a methodology towards multi-scale landslide susceptibility and hazard assessment. vEGU 2021: Gather Online, Apr 2021, Vienne - Online, Austria. 10.5194/egusphere-egu21-14076 . hal-03474550

\section{HAL Id: hal-03474550 https: / hal-brgm.archives-ouvertes.fr/hal-03474550}

Submitted on 10 Dec 2021

HAL is a multi-disciplinary open access archive for the deposit and dissemination of scientific research documents, whether they are published or not. The documents may come from teaching and research institutions in France or abroad, or from public or private research centers.
L'archive ouverte pluridisciplinaire HAL, est destinée au dépôt et à la diffusion de documents scientifiques de niveau recherche, publiés ou non, émanant des établissements d'enseignement et de recherche français ou étrangers, des laboratoires publics ou privés. 
EGU21-14076

https://doi.org/10.5194/egusphere-egu21-14076

EGU General Assembly 2021

(c) Author(s) 2021. This work is distributed under

the Creative Commons Attribution 4.0 License.

\title{
From local to regional 3D litho-structural modelling: a methodology towards multi-scale landslide susceptibility and hazard assessment
}

\author{
Lucie Guillen ${ }^{1,2}$, Séverine Caritg ${ }^{1}$, Pierre Bourbon ${ }^{3}$, Thomas Dewez ${ }^{1}$, Clara Lévy ${ }^{1}$, Alessia \\ Cuccurullo $^{2}$, Christophe Garnier ${ }^{3}$, Domenico Gallipoli, ${ }^{2,4}$, and Yannick Thiery ${ }^{1}$ \\ ${ }^{1}$ Bureau de Recherches Géologiques et Minières, Orléans, France (I.guillen@brgm.fr) \\ ${ }^{2}$ SIAME, Université de Pau et des Pays de l'Adour, Pau, France \\ ${ }^{3}$ BRGM, Pessac, France \\ ${ }^{4}$ Università degli Studi di Genova, Genoa, Italy
}

A 3D litho-structural model synthetizes a geological setting by defining 3D geometries of lithological layers considering stratigraphic relationships, weathering and tectonics. It combines quantitative and qualitative data from different dimensions and acquisition types (field measures and observations, geophysics, boreholes, DEM) into a single structured database. This aesthetic 3D representation enables to work on the same object, despite different sources of datasets, making it a highly useful integrative tool for various ways to monitor and analyze landslides prone areas.

This type of model is used on site scale for large phenomena, for a better understanding of their internal structure and to extract information to be included for failure numerical modelling. However, there are a very few examples of 3D geological models used for large areas subject to spatially limited events. Indeed, the transition from 2D to 3D information remains difficult, especially in case of sparse input data, reinforcing 3D interpretation uncertainties and decreasing the robustness of the model. Thus, most of regional scale geological 3D models used for landslides analyses are simplified and the different lithological layers used for susceptibility and hazard assessments suffer from uncertainties difficult to quantify.

The aim of this contribution is to show how two local scale 3D geological models can contribute and improve the robustness of a regional 3D geological model for the purpose of landslide susceptibility and hazard assessment. The local and regional 3D geological models integrate different data types of uneven quality by successive iterations, to interpret structural and lithological layers geometries with GeoModeller. This software is based on cokriging calculation method of orientation and location of geological interfaces and faults. The regional model will be compared to the local 3D models results, as references to assess regional model uncertainties. This iterative process enables to improve each 3D model with different data sets from one scale to another. Still, models results must be confirmed by field validation to reduce uncertainties as much as possible.

This study focuses on the $40 \mathrm{~km}$ long French Basque coast in the southwest of France, which presents complex faulting and geological heterogeneities inherited from the Pyrenean orogeny - 
these are relatively well mapped along the shore. Both of the local sites are different and characteristic of regional coastal geomorphological types and of specific lithological formations. These are made of flyschs, limestones and marls, the top of which are more or less weathered and capped by Quaternary detritic formations of variable thickness. This coast is subject to various types of shallow and moderately deep instabilities (slides, rockfalls and flows). By defining the geometry of lithology and faults, the 3D models results will enable to:

- Characterize how lithology and structures, as predisposition factors, influence landslides susceptibility to specific landslide types,

- Integrate lithological layers and structural discontinuities to physical-based models to assess landslide susceptibility and hazard on regional $(1: 25,000)$ and on local $(1: 2,500)$ scales,

- Improve the geological knowledge of the French Basque coast. 